\title{
Microclimate and Nest-Site Selection in Micronesian Kingfishers ${ }^{1}$
}

\author{
Dylan C. Kesler ${ }^{2,3}$ and Susan M. Haig ${ }^{3}$
}

\begin{abstract}
We studied the relationship between microclimate and nest-site selection in the Pohnpei Micronesian Kingfisher (Todiramphus cinnamominus reichenbachii) which excavates nest cavities from the mudlike nest structures of arboreal termites (Nasutitermes sp.) or termitaria. Mean daily high temperatures at termitaria were cooler and daily low temperatures were warmer than at random sites in the forest. Results also indicate that termitaria provided insulation from temperature extremes, and that temperatures inside termitaria were within the thermoneutral zone of Micronesian Kingfishers more often than those outside. No differences were identified in temperatures at sites where nest termitaria and nonnest termitaria occurred or among the insulation properties of used and unused termitaria. These results suggest that although termitaria provide insulation from thermal extremes and a metabolically less stressful microclimate, kingfishers did not select from among available termitaria based on their thermal properties. Our findings are relevant to conservation efforts for the critically endangered Guam Micronesian Kingfisher (T. c. cinnamominus) which is extinct in the wild and exists only as a captive population. Captive breeding facilities should provide aviaries with daily ambient temperatures ranging from $22.06{ }^{\circ} \mathrm{C}$ to $28.05^{\circ} \mathrm{C}$ to reduce microclimate-associated metabolic stress and to replicate microclimates used by wild Micronesian Kingfishers.
\end{abstract}

DURING NeSTING, BIRDs employ a broad range of nest-site selection strategies to reduce environmental influences on survival and reproductive success (Ricklefs 1969, Austin 1974, Martin 1992, van Riper et al. 1993,

\footnotetext{
${ }^{1}$ The U.S. Geological Survey Forest and Rangeland Ecosystem Science Center, U.S. Fish and Wildlife Service, Conservation Endowment Fund of the American Zoo and Aquarium Association, National Geographic Society, Disney's Animal Kingdom, St. Louis Zoo Field Research for Conservation Fund, Brookfield Zoo, Friends of the National Zoo, Micronesian Kingfisher Species Survival Fund, Riverbanks Zoo, and Milwaukee County Zoo provided financial backing for this project. Manuscript accepted 27 December 2004.

${ }_{2}^{2}$ (Corresponding author), Department of Fisheries and Wildlife, Oregon State University, Corvallis, Oregon 97331 (phone: 541-760-4433; fax: 541-758-7761; e-mail: dylan_kesler@usgs.gov).

${ }^{3}$ U.S. Geological Survey Forest and Rangeland Ecosystem Science Center, 3200 SW Jefferson Way, Corvallis, Oregon 97331.
}

Pacific Science (2005), vol. 59, no. 4:499-508

Work of the U.S. Government

Not under copyright
With and Webb 1993, Gloutney and Clark 1997, Sheldon and Winkler 1999, Wiebe 2001, Reid et al. 2002). One strategy includes the selection of nest sites in microclimates that reduce metabolic costs to incubating adults (Gloutney et al. 1996, Williams 1996, Thomson et al. 1998) and protect eggs and chicks from mortality and developmental problems (Quinney et al. 1986). Even in generally mild regions, where benefits of microclimate selection are not as intuitively apparent, nest-site selection has been linked to microclimate, exposure to sunlight, prevailing wind, and moisture (van Riper et al. 1993).

Micronesian Kingfishers (Todiramphus cinnamominus) are a tropical species with natural history characteristics that may render them susceptible to thermal stresses. Like other members of the order Coraciiformes, Micronesian Kingfishers hatch as altricial chicks and lack the downy stage of development present in other orders (Fry and Fry 1992). Approximately 3 weeks posthatch, nestlings grow feather-spines that unfurl into feathers. Down feathers provide young in other species 
with insulation for the maintenance of body heat, but because young Micronesian Kingfishers are covered by only skin or featherspines during the first several weeks of growth, they may be more susceptible to thermal stresses and require more parental attention than species with downy chicks.

Results from previous studies indicate that microclimate has the potential to affect reproductive success and nest-site selection in Micronesian Kingfishers. We assessed microclimate conditions provided to captive Guam subspecies of Micronesian Kingfisher (T. $c$. cinnamominus) by evaluating temperatures in aviaries during the 2002 breeding season (Kesler and Haig 2004). Results showed that birds in captive facilities with warmer microclimates were more likely to breed than those in cooler facilities, and that captive aviaries were cooler than areas used by wild Micronesian Kingfishers for nesting. In addition, previous studies of nest-site selection in both wild Guam Micronesian Kingfishers (Marshall 1989) and Pohnpei Micronesian Kingfishers (T. c. reichenbachii) (Kesler and Haig 2005), indicated that the birds selected nests in portions of the rain forest with more contiguous canopy cover, which might limit the heat gain from exposure to sunlight during the daytime and reduce the amount of heat radiated at night.

Together, a taxonomic predisposition to thermal stresses while nesting, a relationship between reproductive success and temperatures in captivity, and selection of dense vegetation for nesting indicate that wild kingfishers may benefit from the selection of nest sites in thermally amenable microclimates. This study was conducted to ascertain whether microclimate temperatures affect nest-site selection in wild Micronesian Kingfishers on the island of Pohnpei. Pohnpei Micronesian Kingfishers construct nest cavities in the mudlike nest structures of arboreal termites (Nasutitermes sp.) or termitaria. We used observations from automated temperature loggers to compare the insulation properties of nest and nonnest termitaria, and the microclimate characteristics of used termitaria, unused termitaria, and random locations in the Pohnpei rain forest. To relate the importance of observed temperatures to kingfisher physiology, results were compared with the thermoneutral zone of adult Micronesian Kingfishers. The thermoneutral zone includes the range of temperatures not requiring metabolic energy for thermoregulation (Calder and King 1974).

Results from this study are intended for use in conservation efforts for the endangered Guam Micronesian Kingfisher, which is extinct in the wild and only exists as a captive population in U.S. zoos (Haig and Ballou 1995, Haig et al. 1995, Bahner et al. 1998, Kesler and Haig 2004). The birds were listed as endangered under the U.S. Endangered Species Act in 1984 following precipitous declines caused by introduced brown trees snakes (Boiga irregularis) (U.S. Fish and Wildlife Service 1984, Savage 1987). Despite nearly $20 \mathrm{yr}$ of effort, attempts to breed captive kingfishers have met with limited success, in part because so little information was available about their behavior in the wild and the conditions they encountered in Guam forests.

\section{Study Area}

Research was conducted on the island of Pohnpei, Federated States of Micronesia $\left(6.88^{\circ} \mathrm{N}, 158.22^{\circ} \mathrm{E}\right)$. Pohnpei is a relatively circular volcanic island with an approximate diameter of $20 \mathrm{~km}$ circumscribing the highest peak (nearly $800 \mathrm{~m}$ elevation) in the Micronesian region. Coastal lowlands and mangrove swamps surround the inner mountain range, which is characterized by dense tropical rain forests. We selected two study areas in Nett $\left(6.95^{\circ} \mathrm{N}, 158.21^{\circ} \mathrm{E}\right)$ and Sokehs municipalities $\left(6.91^{\circ} \mathrm{N}, 158.16^{\circ} \mathrm{E}\right)$ that were $6 \mathrm{~km}$ apart and occurred at approximately $75 \mathrm{~m}$ elevation. Vegetation on the study areas included early succession and agroforest, which was characterized by lower-canopy (2 to $20 \mathrm{~m}$ high) hibiscus (Hibiscus tiliaceus); banana (Musa sapientum); coconut (Cocos nucifera); breadfruit (Artocarpus altilis); and sakau (Piper methysticum). Mature forests had a higher canopy (25-30 $\mathrm{m}$ high) and were dominated by mango (Mangifera indica); dohng (Campnosperma brevipetiolata); sadak (Elaeocarpus carolinensis); 
karara (Myristica insularis); ais (Parinari laurina); and tree ferns (Cyathea spp.) (MuellerDombois and Fosberg 1998, Buden 2000).

\section{MATERIALS AND METHODS}

\section{Temperature Metrics}

Four biologically relevant thermal metrics were used to test for differences in temperatures inside and outside termitaria, between microclimates where nest and nonnest termitaria occur, and between locations where termitaria do and do not occur. The first three metrics were based on temperatures and include mean daily high and low temperatures ( $T_{\max }$ and $T_{\min }$, respectively) and temperature stability (arcsine square root transformed percentage coefficients of variation; $T_{\text {flux }}$ ). The fourth metric incorporated kingfisher physiology by comparing temperatures with the thermoneutral zone of adult Micronesian Kingfishers, which includes the range of temperatures requiring little or no metabolic energy for thermoregulation (Calder and King 1974, Robbins 1993). The upper limit of the thermoneutral zone, or the upper critical temperature, has a mean of $38 \pm$ $3{ }^{\circ} \mathrm{C}$ for most avian species (Aschoff 1981). We estimated the lower limit of the zone, or the lower critical temperature $\left(T_{l}\right)$, for adult Micronesian Kingfishers to be $23.8{ }^{\circ} \mathrm{C}$ using a formula for inactive nonpasserine birds (Robbins 1993):

$$
T_{l c}=T_{b}-38.3 X^{0.31}
$$

where $T_{b}$ is body temperature (estimated as $39.6{ }^{\circ} \mathrm{C}$; King and Farner 1961), and $X$ is mean body weight (58 $\mathrm{g}$ [unpubl. data]). In accordance with Robbins (1993), no adjustments were made to the lower critical temperature to account for energetic costs associated with incubation because of the kingfishers' small one- or two-egg clutch, which averages $28 \%$ mean adult weight. In Pohnpei, ambient air temperature is unlikely to go above the kingfisher thermoneutral zone $(<1 \%$ daily high temperatures [National Oceanic and Atmospheric Administration (NOAA) 2001]) but quite likely to fall below ( $73 \%$ of hourly observations [NOAA 2001]), so the propor- tion of observations below the lower critical temperature (\% below $T_{l}$ ) was the fourth metric compared among site types.

\section{Field Techniques}

Termitaria available to Micronesian Kingfishers were located between May and September 2000. We traversed parallel transects approximately $10 \mathrm{~m}$ apart in forested portions of the study areas using aerial photographs, compasses, and global positioning systems (Garmin, Ltd., Olathe, Kansas) to ensure accuracy. Radio-marked (Holohil Systems, Ltd., Ottawa, Ontario, Canada) Micronesian Kingfishers $(n=26)$ were subsequently followed to identify termitaria used for nesting. In the 43.4-ha search area, 21 nest and 234 nonnest termitaria were located.

Temperature sampling was conducted during two sessions. The thermal characteristics of microclimates surrounding termitaria were sampled during the kingfisher breeding season between 6 and 16 September 2001. Temperatures were recorded at nest and nonnest termitaria and at random sites in the forest using temperature loggers (StowAway, Onset Computer Corp., Pocasset, Massachusetts). Loggers were placed immediately below $(<5$ $\mathrm{cm})$ nest termitaria $(n=18)$ on both study areas, at 19 nonnest termitaria randomly selected from a candidate list of 107 termitaria of enough volume for kingfisher use $(>14$ liters in volume [Kesler and Haig 2005]), and at 21 forested locations without termitaria. Nontermitaria locations were randomly selected from a 1-m grid overlaid on the census search areas with a geographic information system (GIS) (ArcView, ESRI, Redlands, California) database. Loggers were placed at a height and orientation randomly selected from the height and orientation distributions of nest termitaria.

Temperatures fluctuate throughout the day in Pohnpei, but daily means are extremely stable both within and among years (mean daily temperature $=27.2 \pm 0.99{ }^{\circ} \mathrm{C}$ SD [NOAA 2001]) and suggest that even short-duration monitoring is likely representative of overall thermal patterns. Thus, loggers were set to record ambient temperatures at 6-min inter- 
vals during each of three 3-day assessment periods starting at $1900 \mathrm{hr}$ on 6,10 , and 14 September 2001.

To determine how temperatures inside termitaria differed from those in the surrounding microhabitat, we also conducted an evaluation of termitaria insulation characteristics. We initiated sampling after the 2002 breeding season to reduce disturbance to nesting birds. Temperatures were recorded by pairs of loggers placed inside and outside 18 termitaria on the Nett study area between 27 December 2002 and 8 January 2003. We previously observed nesting kingfishers in twelve of the termitaria, and six were large enough to contain nest cavities ( $>14$ liters [Kesler and Haig 2005]). We inserted one temperature logger $15 \mathrm{~cm}$ into each sample termitarium (approximate kingfisher nest chamber depth [Kesler and Haig 2005]), and another logger was placed $5 \mathrm{~cm}$ below each of the termitaria. The pairs of loggers were set to record temperatures simultaneously, every $6 \mathrm{~min}$ and for 48 -hr periods at each sample site. No comparison could be made between successful and unsuccessful nests because Pohnpei residents, who destroyed nests with machetes, caused the only nest mortality that we observed during five field seasons (Kesler and Haig 2005).

\section{Statistical Analysis}

Temperature characteristics at nest, nonnest, and nontermitarium sites were assessed using models with variables for site type and observation period. We used repeated measures analysis of variance (RANOVA; SAS Analyst [SAS Institute 1999]) to evaluate models for $T_{\max }$ and $T_{\min }$ and a mixed models analysis of variance (PROCMIX [SAS Institute 1999]) to assess $T_{\text {fuux }}$ and \% below $T_{k}$. Estimates for least squares means were used in two orthogonal linear contrasts (Ramsey and Schafer 1997) to compare microhabitat thermal characteristics of nest with nonnest termitaria, and all termitaria with nontermitaria sites. Repeated measures models were fitted using compound symmetry (CS), unstructured (U), and firstorder autoregressive (FOA) covariance structures, and results are reported for the model with the lowest Akaike Information Criteria value (AIC) (Burnham and Anderson 1998).

Thermal regimes inside termitaria were compared with those outside with RANOVA for $T_{\max }$ and $T_{\min }$, and a paired $t$-test for $T_{f u x}$ and \% below $T_{l c}$. Similarly, we compared the insulation properties of nest and nonnest termitaria by evaluating the difference in thermal metrics recorded inside and outside each termitarium with RANOVA for $T_{\max }$ and $T_{\min }$ and two sample $t$-tests for $T_{f u x}$ and $\%$ below $T_{l}$. Parameter estimates are reported as means \pm standard error (SE) unless otherwise noted, and differences are considered statistically significant at $\alpha \leq 0.05$. All variables were treated separately and $95 \%$ confidence intervals (CI) are presented.

\section{RESULTS}

Temperatures logged during the breeding season showed similar daily patterns (Figure 1). Beginning shortly after sunrise (approximately $0700 \mathrm{hr}$ ), temperatures climbed to a midday peak at approximately $1000 \mathrm{hr}$. Mean daily high temperatures during the breeding season $\left(29.4 \pm 1.9^{\circ} \mathrm{C}\right)$ remained below the upper critical temperature (approximately $38 \pm 3^{\circ} \mathrm{C}$ ). Afternoon temperatures fluctuated and began to fall at approximately 1500 hours. Nocturnal temperatures fell to a mean low of $22.8 \pm 0.7^{\circ} \mathrm{C}$. The low temperature trough lasted from approximately 0000 to 0730 hours ( $25 \pm 5 \%$ for each 24 -hr period).

All four thermal metrics differed between sites with termitaria and random forested sites without termitaria (Table 1). Contrasts of least square means showed that mean $T_{\max }$ was $0.93{ }^{\circ} \mathrm{C}$ lower at termitaria $(\mathrm{CS}, F=7.7$; $\mathrm{df}=1,54 ; P=0.007$; CI $\left.0.26-1.60{ }^{\circ} \mathrm{C}\right)$ than at sites where termitaria did not occur. Mean $T_{\min }$ at sites with termitaria was significantly warmer (FOA, $F=56.3$; $\mathrm{df}=1,86$; $P<0.0001)$ than at nontermitaria sites, but the estimated difference in magnitude was small $\left(0.20^{\circ} \mathrm{C}\right.$; CI $\left.0.10-0.29{ }^{\circ} \mathrm{C}\right)$. Temperatures fluctuated less where termitaria occurred than where termitaria did not occur (back transformed $T_{\text {fux }} 0.12 \%$ higher in nontermitaria; $F=11.4 ; \mathrm{df}=1,54 ; P=0.001$; $\mathrm{CI}<0.01-0.39 \%)$. Similarly, the proportion 


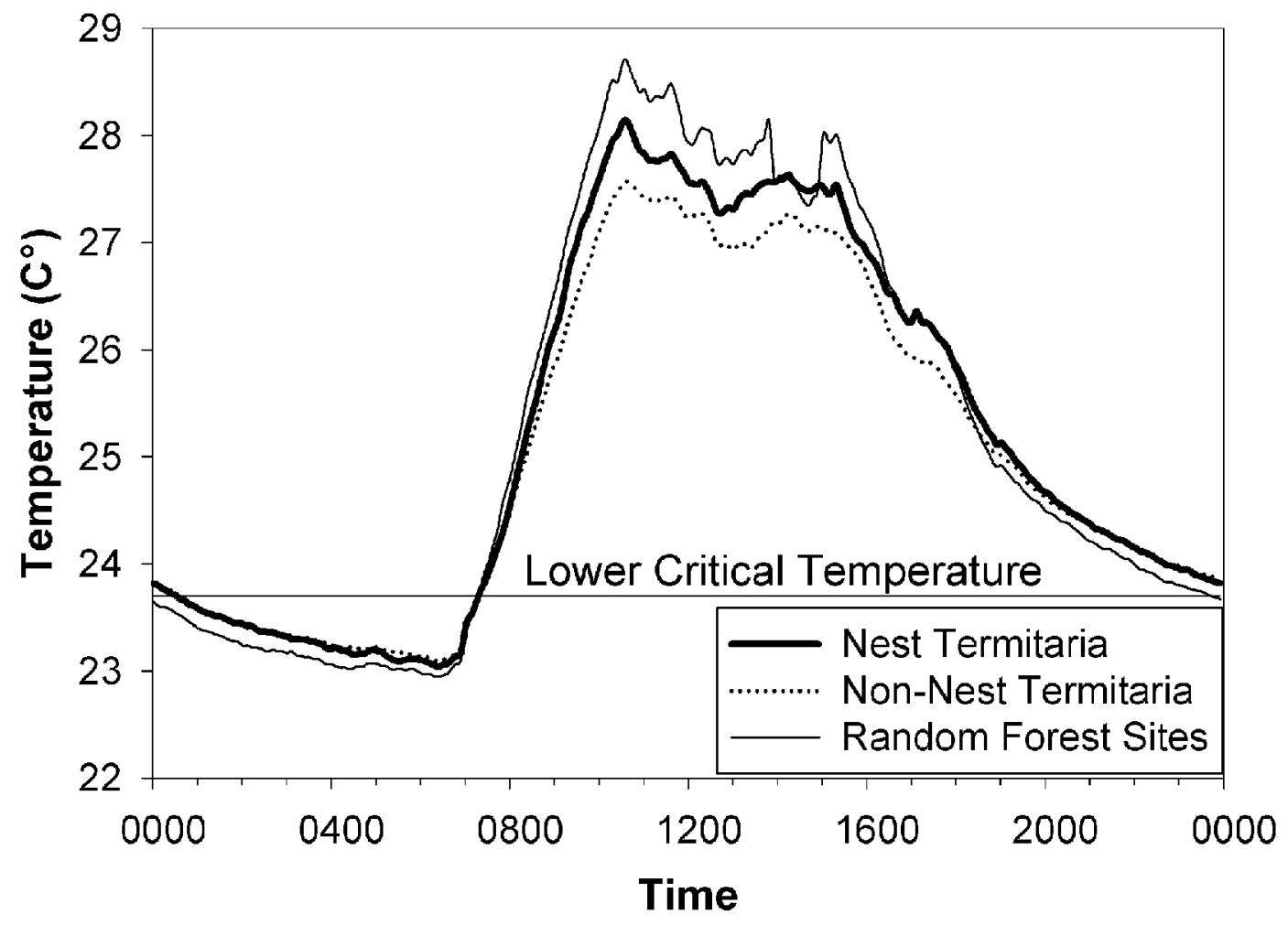

Figure 1. Lower critical temperature of adult Pohnpei Micronesian Kingfishers and mean hourly temperatures from microhabitats at 18 nest termitaria, 19 nonnest termitaria, and 21 random forest locations on Pohnpei in September 2001.

\section{TABLE 1}

Least Squares Means and SE for Estimated Temperatures in Microhabitats Surrounding Pohnpei Micronesian Kingfisher Nest Termitaria, Nonnest Termitaria, and Forest Locations without Termitaria on Pohnpei in September 2001

\begin{tabular}{lccc}
\hline \hline $\begin{array}{l}\text { Thermal } \\
\text { Metric }\end{array}$ & $\begin{array}{c}\text { Nest } \\
\text { Termitaria } \\
(n=18)\end{array}$ & $\begin{array}{c}\text { Nonnest } \\
\text { Termitaria } \\
(n=19)\end{array}$ & $\begin{array}{c}\text { Forest } \\
(n=21)\end{array}$ \\
\hline$T_{\max }\left({ }^{\circ} \mathrm{C}\right)$ & $28.05(0.41)$ & $27.71(0.40)$ & $28.70(0.39)$ \\
$T_{\min }\left({ }^{\circ} \mathrm{C}\right)$ & $22.86(0.11)$ & $22.91(0.11)$ & $22.72(0.11)$ \\
$T_{\text {flux }}(\%)^{a}$ & $7.32(0.02)$ & $6.57(0.02)$ & $8.26(0.02)$ \\
$\%$ below $T_{l c}{ }^{b}$ & $28.7(2.6)$ & $27.3(2.6)$ & $31.7(2.5)$ \\
\hline
\end{tabular}

a Arcsine square root transformed for analysis and back transformed for presentation as $\mathrm{CV}$.

${ }^{b}$ Proportion of 6-min temperature observations below the lower critical temperature for adult Micronesian Kingfishers. of time when temperatures were below the lower critical temperature was estimated to be $3.4 \%$ greater $(F=5.8 ; \mathrm{df}=1,54 ; P=$ 0.019 ; CI $0.5-6.3 \%$ ) in nontermitaria microclimates than in microclimates with termitaria. No differences were identified in microhabitat temperatures at nest and nonnest termitaria for any metric.

Differences between temperatures inside and outside termitaria were identified for all four thermal metrics, illustrating that the termitarium itself provides insulation and a buffer from environmental extremes. Temperatures observed outside termitaria had a mean $T_{\max } 0.55{ }^{\circ} \mathrm{C}$ warmer (CS, $F=5.0$; $\mathrm{df}=1,89 ; P=0.03 ;$ CI $\left.0.06-1.06{ }^{\circ} \mathrm{C}\right), T_{\min }$ $1.00{ }^{\circ} \mathrm{C}$ cooler $(\mathrm{CS}, F=26.8$; $\mathrm{df}=1,89$; $P<0.001$; CI $0.62-1.38{ }^{\circ} \mathrm{C}$ ), back transformed $T_{\text {flux }} 0.25 \%$ less stable $(P<0.001$; CI $0.09-0.49 \%)$, and temperatures were below 


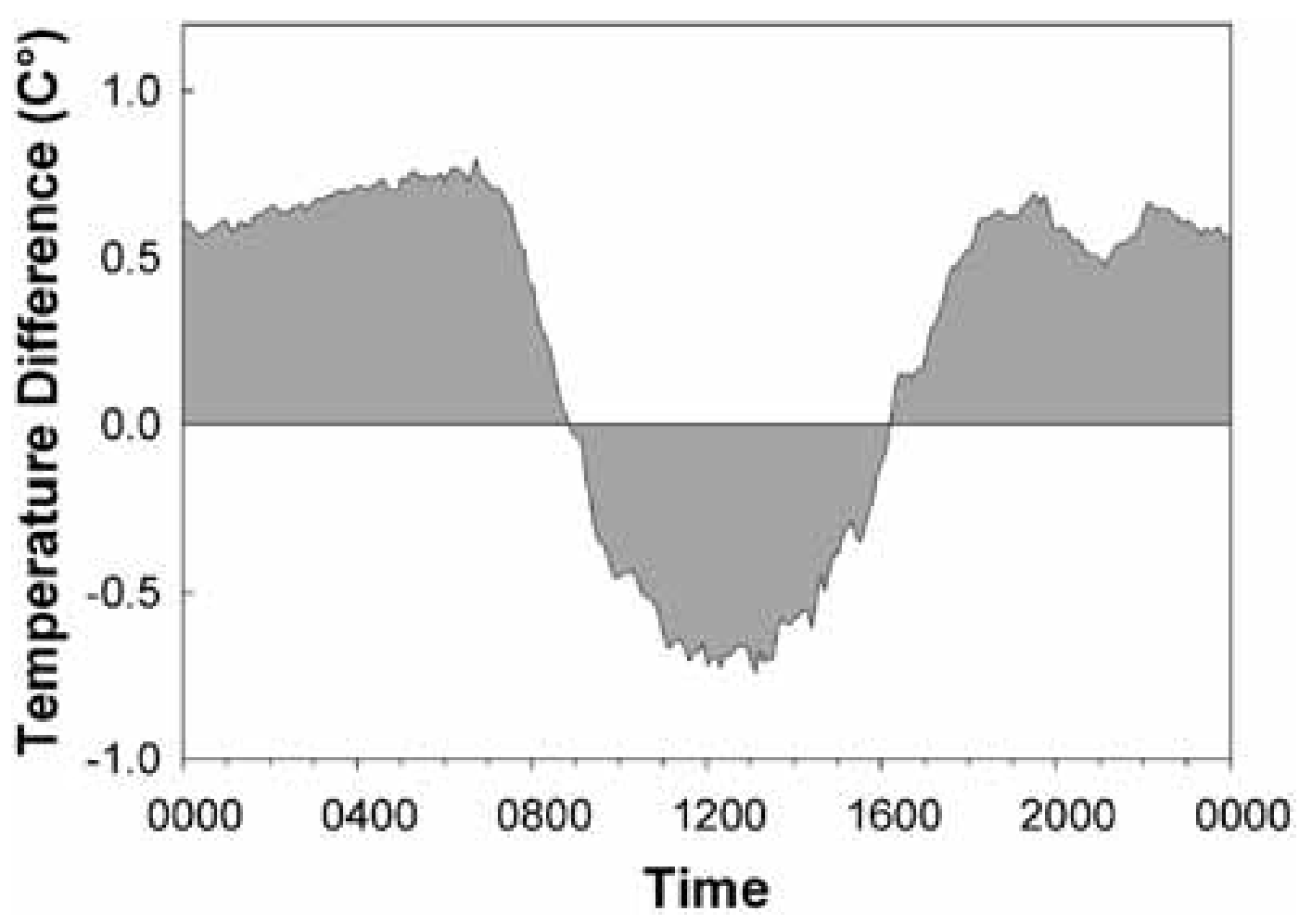

Figure 2. Mean difference in temperatures outside and inside termitaria on Pohnpei in December 2002. Positive values indicate warmer temperatures inside termitaria and negative values indicate cooler termitaria temperatures.

the $T_{k} 5.7 \%$ more often $(P=0.02$; CI $1-$ $10 \%)$ than temperatures inside termitaria. When compared with those outside termitaria, temperatures inside were warmer during the coolest portions of the day (from 1612 to 0848 hours) and cooler during 7.3 daylight hours (Figure 2). In contrast, no differences were found for any of the four metrics when comparing temperature disparities at nest and nonnest termitaria.

\section{DISCUSSION}

Nests in locations with temperatures closely aligned to the thermoneutral zone are likely to conserve metabolic energy and thereby benefit fitness and survival (White and Kinney 1974). During the breeding season, temperatures at sites where termitaria occurred were within the thermoneutral zone of $\mathrm{Mi}$ cronesian Kingfishers more often than at sites where termitaria did not occur. Arboreal termites tend to construct termitaria in forested locations with greater canopy development and overhead vegetative cover (Marshall 1989, Kesler 2002, Kesler and Haig 2004, 2005). This additional cover might reduce both the heat gain from exposure to sunlight during the daytime and the amount of heat radiated at night. The effects of heat gain from sunlight and radiative cover have been investigated previously (e.g., Calder 1974, Campbell 1977, Walsberg 1981, Wiebe and Martin 1998). Calder (1973) estimated differences of $1-6^{\circ} \mathrm{C}$ in the temperatures of Anna's Hummingbird (Calypte anna) nests with and without radiative cover, and Gloutney and Clark (1997) suggested that vegetative cover kept Blue-winged Teal (Anas discors) and Mallard (Anas platyrbynchos) nests cooler during daylight hours.

Convective heat losses from air movement 
and evaporative heat losses associated with moisture are additional factors that may influence thermoregulation (Ricklefs and Hainsworth 1969, McArthur 1987, van Riper et al. 1993, With and Webb 1993, Gloutney and Clark 1997). The small entrance and cavity structure of Micronesian Kingfisher nests (Kesler and Haig 2005) suggest that they are probably protected from convective heat losses, but losses associated with moisture may be extremely important on Pohnpei, which receives a mean yearly rainfall of 473 cm (NOAA 2001). Arboreal termites likely select the driest of sites for termitarium construction because the mudlike composition of their nests makes them susceptible to rain. Therefore, Micronesian Kingfishers may derive benefit from the combined temperature and moisture properties of microclimates selected first by termites and then secondarily by the kingfishers.

The estimated temperature differences between microhabitat types were small $\left(<1^{\circ} \mathrm{C}\right)$, and temperatures at all sample locations during the breeding season did not differ drastically from the thermoneutral zone for adult kingfishers. However, even slight differences in thermal regime may be extremely important to nestlings. Adult kingfishers spend little time brooding nestlings, whose plumage is relatively undeveloped until approximately 3 weeks posthatch (D.C.K., unpubl. data). This suggests that nestlings are likely to have an elevated lower critical temperature when compared with adults and therefore derive greater benefit from nests providing insulation, located in warmer microclimates, or sheltered from moisture and the associated evaporative heat losses. In addition, statistically significant differences of less than a degree have been observed between successful, unused, and unsuccessful Mountain Chickadee (Parus gambeli) nest boxes (Wachob 1996).

The amount of metabolic energy expended by nesting Micronesian Kingfishers for thermoregulation and incubation is influenced by both the thermodynamic properties of the termitarium in which a nest cavity is located and the thermal regime of the site where the termitarium occurs. Differences in tem- peratures observed inside and outside termitaria demonstrate that termitaria serve as a buffer from thermal extremes. These insulation properties, coupled with the occurrence of termitaria at sites with thermal regimes closely aligned to the kingfisher thermoneutral zone, suggest that the use of termitaria benefits Micronesian Kingfishers. However, our failure to detect a difference in insulation properties and thermal regimes of termitaria used for nesting and those that were not suggests that Micronesian Kingfishers do not select from among termitaria based on thermal characteristics.

Differences among sites should be great enough to alter survival or reproductive success for microhabitat thermal characteristics to affect nest-site selection. Therefore, the apparent lack of temperature consideration when selecting from among termitaria may be related to the generally suitable temperature range of sites where termitaria occur or to the trade-offs associated with selecting nest sites based on thermal characteristics. Microhabitat temperature at nest and nonnest termitaria did not extend above the upper critical temperature, and although it dipped below the lower critical temperature for $32 \%$ of the observations the magnitude was only $1.4{ }^{\circ} \mathrm{C}$ and $1.3{ }^{\circ} \mathrm{C}$, respectively (Table 1 ). The proportion of time that temperatures were below the lower critical temperature at termitaria is similar to the $25 \%$ found for Mallards but contrasts with the $50 \%$ observed for Blue-winged Teal (Gloutney and Clark 1997). A comparison of temperatures at nest and nearby nonnest sites for these species also resulted in nonsignificant differences in ambient air temperature. Although there have been numerous investigations of microclimate in other cavity nesting species (e.g., Ricklefs and Hainsworth 1969, Austin 1974, Wachob 1996, Wiebe 2001), we found none that compared observed temperatures with the thermoneutral zone.

The entire population of the Guam subspecies of Micronesian Kingfisher currently exists in captive breeding facilities. However, observers noted that the birds nested in both termitaria and soft-wooded trees before their extirpation from Guam (Jenkins 1983, 
Marshall 1989). Although we were unable to evaluate difference between the thermal characteristics of nest cavities constructed in wood and those in termitaria, cavities made in wood by Acorn Woodpeckers, Melanerpes formicivorus, and Northern Flickers, Colaptes auratus, have also been shown to provide protections from solar heat gain and convective and radiative heat losses (Hooge et al. 1999, Wiebe 2001). Thus, historic Guam Micronesian Kingfisher nest sites probably also provided thermal buffering, regardless of the substrate in which they occurred.

Our results showed that the wild subspecies of Micronesian Kingfisher on Pohnpei was rarely exposed to temperatures outside its thermoneutral zone while nesting and that birds did not select from among available termitaria based on site thermal character. Thus, we suggest that captive facilities attempting to propagate Micronesian Kingfishers for conservation purposes should closely match the ambient temperatures described here (ranging from 22.06 to 28.05 $\left.{ }^{\circ} \mathrm{C}\right)$. Furthermore, we suggest that substrates with adequate insulation properties be provided to captive birds for nest-cavity excavation. With regard to conservation planning for a reintroduction of Micronesian Kingfishers to Guam (U.S. Fish and Wildlife Service 2004), and Pacific island kingfishers in general, we suggest that appropriate measures be taken to avoid metabolic stresses associated with microclimate by providing suitable nesting habitats with ambient temperatures falling close to the thermoneutral zone.

\section{ACKNOWLEDGMENTS}

We are indebted to all those who provided financial and technical support to the project. R. Anthony, M. Huso, S. Derrickson, and F. Ramsey provided valuable technical and planning advice. We thank P. Sanzenbacher and O. Taft for their comments on the manuscript. D. Buden and B. Raynor provided advice on Pohnpei. We also extend thanks to H. Anson, R. Mauricio, and the landowners in Pohnpei. M. Boris, P. Sanzenbacher, J. Santos, and C. Cantero also made contributions as field assistants and cultural guides.

\section{Literature Cited}

Aschoff, J. 1981. Thermal conductance in mammals and birds: Its dependence on body size and circadian phase. Comp. Biochem. Physiol. A Comp. Physiol. 69:611619.

Austin, G. T. 1974. Nesting success of the Cactus Wren in relation to nest orientation. Condor 76:216-217.

Bahner, B., A. Baltz, and E. Diebold. 1998. Micronesian Kingfisher species survival plan husbandry manual. Zoological Society of Philadelphia, Philadelphia, Pennsylvania.

Buden, D. W. 2000. A comparison of 1983 and 1994 bird surveys of Pohnpei, Federated States of Micronesia. Wilson Bull. 112:403-410.

Burnham, K. P., and D. R. Anderson. 1998. Model selection and inference: A practical information-theoretic approach. Springer, New York.

Calder, W. A. 1973. Microhabitat selection during nesting of hummingbirds in the Rocky Mountains. Ecology 54:127-134.

. 1974. The thermal and radiant environment of a winter hummingbird nest. Condor 76:268-273.

Calder, W. A., and J. R. King. 1974. Thermal and caloric relations of birds. Pages 259413 in D. S. Farner and J. R. King, eds. Avian biology. Vol. 4. Academic Press, New York.

Campbell, G. S. 1977. An introduction to environmental biophysics. Springer-Verlag, New York.

Fry, C. H., and K. Fry. 1992. Kingfishers, bee-eaters, and rollers. Princeton University Press, Princeton, New Jersey.

Gloutney, M. L., and R. G. Clark. 1997. Nest-site selection by Mallards and Bluewinged Teal in relation to microclimate. Auk 114:381-395.

Gloutney, M. L., N. West, and R. G. Clark. 1996. Metabolic costs of incubation and clutch size determination in Red Junglefowl. Comp. Biochem. Physiol. A Comp. Physiol. 114:265-270.

Haig, S. M., and J. D. Ballou. 1995. Genetic diversity in two avian species formerly endemic to Guam. Auk 112:445-455. 
Haig, S. M., J. D. Ballou, and N. J. Casna. 1995. Genetic identification of kin in Micronesian Kingfishers. J. Hered. 86:423431.

Hooge, P. N., M. T. Stanback, and W. D. Koenig. 1999. Nest-site selection in the Acorn Woodpecker. Auk 116:45-54.

Jenkins, J. M. 1983. The native forest birds of Guam. Ornithol. Monogr. 31.

Kesler, D. C. 2002. Nest site selection in cooperatively breeding Pohnpei Micronesian Kingfishers (Halcyon cinnamomina reichenbachii): Does nest-site abundance limit reproductive opportunities? M.S. thesis, Oregon State University, Corvallis.

Kesler, D. C., and S. M. Haig. 2004. Thermal characteristics of wild and captive Micronesian Kingfisher nesting habitats. Zoo Biol. 23:301-308.

- 2005. Selection of arboreal termitaria for nesting by cooperatively breeding Micronesian Kingfishers, Todiramphus cinnamominus reichenbachii. Ibis 147:188-196.

King, J. R., and D. S. Farner. 1961. Energy metabolism, thermoregulation and body temperature. Pages 215-288 in A. J. Marshall, ed. Biology and comparative physiology of birds. Vol. 2. Academic Press, New York.

Marshall, S. D. 1989. Nest sites of the Micronesian Kingfisher on Guam. Wilson Bull. 101:472-477.

Martin, T. E. 1992. Avian life history evolution in relation to nest-sites, nest predation and food. Ecol. Monogr. 65:101-127.

McArthur, A. J. 1987. Thermal interaction between animal and microclimate: Specification of a standard environmental temperature for animals outdoors. J. Theor. Biol. 126:203-238.

Mueller-Dombois, D., and F. R. Fosberg. 1998. Vegetation of the tropical Pacific islands. Springer, New York.

National Oceanic and Atmospheric Administration (NOAA). 2001. National virtual data system (www.noaa.gov/).

Quinney, T. E., D. J. Hussel, and C. D. Ankney. 1986. Sources of variation in growth of Tree Swallows. Auk 103:389-400.

Ramsey, F. L., and D. W. Schafer. 1997. The statistical sleuth: A course in methods of data analysis. Duxbury Press, Belmont, California.

Reid, J. M., G. D. Ruxton, P. Monaghan, and G. M. Hilton. 2002. Energetic consequences of clutch temperature and clutch size for a uniparental intermittent incubator: The Starling. Auk 119:54-61.

Ricklefs, R. E. 1969. An analysis of nesting mortality in birds. Smithson. Contrib. Zool. 9.

Ricklefs, R. E., and F. R. Hainsworth. 1969. Temperature regulation in nesting Cactus Wrens: The nest environment. Condor 71:32-37.

Robbins, C. T. 1993. Wildlife feeding and nutrition. Academic Press, San Diego, California.

SAS Institute. 1999. The SAS system for Windows. Cary, North Carolina.

Savage, J. A. 1987. Extinction of an island forest avifauna by an introduced snake. Ecology 68:660-668.

Sheldon, F. H., and D. W. Winkler. 1999. Nest architecture and avian systematics. Auk 116:875-877.

Thomson, D. L., P. Monaghan, and R. W. Furness. 1998. The demands of incubation and avian clutch size. Biol. Rev. 73:293304.

U.S. Fish and Wildlife Service. 1984. Endangered and threatened wildlife and plants: Determination of endangered status for seven birds and two bats on Guam and the Northern Mariana Islands. Fed. Reg. 49:33881-33885.

- 2004. Draft revised recovery plan for the Sihek or Guam Micronesian Kingfisher (Halcyon cinnamomina cinnamomina). Fed. Reg. 69:23210-23211.

van Riper III, C., M. D. Kern, and M. K. Sogge. 1993. Changing nest placement of Hawaiian Common Amakihi during the breeding cycle. Wilson Bull. 105:436447.

Wachob, E. G. 1996. A microclimate analysis of nest-site selection by Mountain Chickadees. J. Field Ornithol. 67:525-533.

Walsberg, G. E. 1981. Nest-site selection and the radiative environment of the Warbling Vireo. Condor 83:86-88.

White, F. N., and J. L. Kinney. 1974. Avian 
incubation. Science (Washington, D.C.) 186:107-115.

Wiebe, K. L. 2001. Microclimate of tree cavity nests: Is it important for reproductive success in Northern Flickers? Auk 118:412-421.

Wiebe, K. L., and K. Martin. 1998. Costs and benefits of nest cover for ptarmigan: Changes within and between years. Anim. Behav. 56:1137-1144.
Williams, J. B. 1996. Energetics of avian incubation. Pages 375-415 in C. Carey, ed. Avian energetics and nutritional ecology. Chapman and Hall, London.

With, K. A., and D. R. Webb. 1993. Microclimate of ground nests: The relative importance of radiative cover and wind breaks for three grassland species. Condor 95:401-413. 